\title{
Perceptions of working conditions amongst health workers in state-owned facilities in northeastern Nigeria
}

\author{
Oluwabunmi O. Chirdan, Joeseph T. Akosu, Clara L. Ejembi ${ }^{1}$, Amos P. Bassi' ${ }^{2}$, Ayuba I. Zoakah \\ Departments of Community Medicine, Jos University Teaching Hospital, Jos, Plateau State, ${ }^{1}$ Community \\ Medicine, Ahamadu Bello University Teaching Hospital, Zaria, Kaduna State, ${ }^{2}$ Community Medicine, University \\ of Maiduguri Teaching Hospital, Maiduguri, Borno State, Nigeria
}

Correspondence to: Dr. Oluwabunmi O. Chirdan, Department of Community Medicine, Jos University Teaching Hospital, PMB 2076, Jos, Nigeria. E-mail: yemisichirdan@yahoo.com

\begin{abstract}
Background: The health care sector depends to a large extent on human labor. Poor worker motivation can greatly affect health outcomes and patient safety. There is little information on the health workers' perceptions of working conditions in resource-poor settings.

Method:Three state-owned facilities in each state were selected by simple random sampling technique. The selected facilities were visited on weekdays between 9 and 10 a.m. A self-administered structured questionnaire was given to all health care workers on duty in the facility at the time of visit.

Results: A total of 299 questionnaires were returned. The response rate was $85.43 \%$. Two hundred four (68.2\%) workers experienced general satisfaction with their current jobs. The relationships between general job satisfaction and presence of conflict at work $(P=0.001)$, freedom of expression $(P>0.001)$, managerial support for staff welfare $(P>0.001)$, managerial support for staff career development $(P>0.001)$, availability of tools and consumables in the workplace $(P>0.001)$ and progress towards personal professional goals $(P=0.001)$ were statistically significant. Conclusion: The level of general job satisfaction was high. Though salaries were important, presence of conflict at work, freedom of expression, managerial support for staff welfare, managerial support for staff career development, availability of tools and consumables in the workplace and progress towards personal professional goals appear to play a role in worker motivation.
\end{abstract}

Keywords: Health worker, job satisfaction, northeastern Nigeria, workplace

\section{Résumé}

Arrière-plan: Le secteur des soins de santé dépend dans une large mesure homme main de œuvre. Travailleur pauvre motivation peut affecter considérablement des résultats pour la santé et le patient sécurité. Il y a peu d'informations dans les paramètres de ressources limitées de travailleurs de la santé perception.

Méthode: Trois Etats appartenant installations dans chaque État ont été sélectionnées. par un échantillonnage aléatoire simple technique. Les installations sélectionnées ont été visitées sur jours de semaine entre 9-10 h 00. Un questionnaire structuré self -administered a été. donné à tous les travailleurs de la santé en mission dans l'établissement au moment de visitez.

Résultats: Un total de 299 questionnaires ont été retournés. La réponse. taux était de $85.43 \%$. Deux cent et quatre $(68.2 \%)$ a connu la satisfaction générale avec leurs travaux en cours. La relation entre la satisfaction au travail général et présence de conflits au travail $P=0.001$, la liberté d'expression $P>0.001$, gestion de la prise en charge de $p$ de bien-être personnel $>0.001$, dirigeant d'entreprise prennent en charge pour le personnel p de développement de carrière $>0.001$, disponibilité des outils et des consommables dans les lieu de travail $P>0.001$ et les progrès vers les objectifs professionnels personnels $P=0.001$ étaient statistiquement significatifs.

Conclusion: Le niveau de satisfaction au travail général était élevé. Bien que salaires étaient importants, présence de conflits au travail, la liberté d'expression, gestion de la prise en charge pour le bien-être personnel, gestion de la 
prise en charge de carrière du personnel développement, la disponibilité des outils et des consommables sur le lieu de travail et progrès vers les objectifs professionnels personnels, semblent jouer un rôle dans travailleur motivation.

Mots clés: Agent de santé, la satisfaction au travail, lieu de travail, du Nord orientale Nigeria

DOI: $10.4103 / 1596-3519.59579$

\section{Introduction}

Page | 244

Worker motivation is the degree of willingness of the worker to exert and maintain an effort towards organizational goals. ${ }^{[1]}$ There are many theories concerning job motivation, but this article looks at the Herzberg's theory. However, this article looks at the Herzberg theory which identifies two types of motivation.

Motivation to accept a post and to remain at that post is related to meeting needs of job security, salary, etc. An organization or institute can attract and retain personnel in their posts through salaries; allowances; and working conditions, such as the availability of equipment, communication and relationship with colleagues. When working conditions are not perceived to be satisfactory by health workers, they are likely to find ways to compensate for this. For instance, they will become more concerned with earning enough to cover their basic needs in ways other than to concentrate on their public service job. In Herzberg's theory, these are called "factors for dissatisfaction (dissatisfies)." These dissatisfies are mainly extrinsic factors. ${ }^{[2]}$ Dissatisfies are said to be the main causes of poor job satisfaction. They include working conditions, salary, relationship with colleagues, administrative supervision, etc. ${ }^{[3]}$

The second type of motivation is motivation to improve performance. This is linked to a feeling of self-fulfillment, achievement and recognition. ${ }^{[4,5]}$ These feelings can be influenced by effective performance management, through which managers ensure that staff are competent and motivated in their job. ${ }^{[6]}$ It involves supervision, training, performance appraisal and career development. Examples of motivating factors are achievement, recognition, responsibility and the work itself.

However, worker motivation is not an attribute of the individual or the organization; rather, it results from an interaction between the worker and the work environment. Hence policy and social environment can affect it, ${ }^{[7]}$ e.g., the quality of one's relationship with his/her supervisor, the quality of the physical environment in which one works, societal values and expectations, as well as resource availability and management.

The health care sector is important, and the quality and efficiency of service depend to a large extent on human labor. Poor worker motivation can greatly affect health outcomes and patient safety. Poor worker motivation is common and can manifest as lack of courtesy to patients; tardiness and absenteeism; poor process quality, such as failure to conduct proper patient examinations; and failure to treat patients in a timely manner. ${ }^{[8]}$ In the workforce, it can manifest in high staff turnover rates, high vacancy rates and indifferent performance. ${ }^{[1]}$

To improve performance of the health sector, health care managers need to influence factors that motivate health workers and cause job satisfaction amongst them. However, this is under-performed in the public health sector in resource-poor settings. This is so probably because there is little information in these countries on factors that influence workers' motivation.

It is important to know the factors that affect worker motivation amongst the health care workers. These issues are important. A worker may be competent, but what makes the individual come to work regularly, work diligently and be willing to carry out necessary tasks and be flexible is his/her level of motivation. ${ }^{[1]}$

Since the beginning of the economic crisis in the 1980s, the health sector has suffered dramatically, as has all other public service activity. The decline in the health sector is evidenced by worsening of the health indices. This has resulted in an exodus of health professionals to the extent that Nigeria, one of the major exporters of health personnel in Africa, ${ }^{[9]}$ Knowledge of health workers' perceptions of working conditions and their job satisfaction can be exploited by managers to improve health sector performance.

This study assesses perceptions of working conditions, i.e., those related to workload, salary, quality of supervision, staff welfare, career development, etc., amongst health care workers in northeastern Nigeria.

\section{Background of north eastern Nigeria}

Northeastern zone is one of the six geopolitical zones in Nigeria. It has six states: Adamawa, Bauchi, Borno, Gombe, Taraba and Yobe.

The state ministries of health manage general hospitals, which are secondary level facilities; and each of the 
states has a specialist hospital, which offers tertiary care. However, inadequacy of financial resources (US \$2-3 per capita) for the health sector is a major problem. ${ }^{[10]}$ Due to economic crisis, there has been a decline in recurrent expenditure, resulting in a scarcity of drugs and medical supplies and deterioration of facilities in Nigeria, northeastern zone inclusive.

\section{Materials and Methods}

\section{Study design}

The study was a cross-sectional study of state-owned health facilities in northeastern Nigeria.

\section{Study population}

The study comprised of health care workers in selected facilities.

\section{Sampling method}

A list of all secondary level facilities in each state was made. From the list, two facilities in each state were selected by simple random sampling technique. All existing tertiary health facilities owned by the state governments in each state were selected.

\section{Selection of health workers}

The selected facilities were visited on weekdays between 9 and 10 a.m. over a period of 2 weeks. The purpose of the study was explained to the management of the facility, and permission was obtained at all sites. All departments (both clinical and support services) in each health facility were included in the study. Table 1 shows the list of health workers recruited into the study by state.

In each department, a list of all workers scheduled to be on duty at the time of the assessment was made. Using that list, the entire staff at work during the period of the visit was identified, and informed consent was obtained. A self-administered semi-structured questionnaire was given to all health care workers identified. The questionnaire explored the effect of monetary factors, societal expectations, interpersonal relationships, quality of supervision and managerial characteristics on the health workers' job satisfaction.

\section{Data analysis}

The questionnaires were collected and information was collated and analyzed using SPSS 10 statistical package.

\section{Limitations}

Though the researchers tried to dispel fear of retribution by ensuring anonymity in the questionnaires, we could not ascertain the validity of the responses of the health workers.

\section{Results}

A total of 350 questionnaires were distributed, of which 299 were returned; the response rate was $85.43 \%$.

One hundred ninety-one (63.9\%) of the respondents were males and 108 (36.1\%) were females [Table 2]. One hundred fifty-eight (52.8\%) were aged 31 to 40 years [Table 2].

Page | 245

One hundred forty-nine (49.8\%) of the respondents were nurses; 33 (11\%), doctors; 26, laboratory scientists $(8.7 \%) ; 10(3.3 \%)$, pharmacists; and $81(27.1 \%)$, support staff, which included ward attendants, pharmacy attendants, catering staff and record clerks. Eighty (26.8\%) workers had been on the present job for 5-10 years.

\begin{tabular}{|c|c|c|}
\hline State & Name of hospital & $\begin{array}{l}\text { Number of workers } \\
\text { recruited in study }\end{array}$ \\
\hline \multirow[t]{4}{*}{ Adamawa } & $\begin{array}{l}\text { Specialist } \\
\text { Hospital, Yola }\end{array}$ & 19 \\
\hline & General & 15 \\
\hline & Hospital, Mubi & \\
\hline & $\begin{array}{l}\text { General Hospital, } \\
\text { Numan }\end{array}$ & 14 \\
\hline \multirow[t]{3}{*}{ Bauchi } & $\begin{array}{l}\text { Specialist } \\
\text { Hospital, Bauchi }\end{array}$ & 18 \\
\hline & $\begin{array}{l}\text { General Hospital, } \\
\text { Ningi }\end{array}$ & 13 \\
\hline & $\begin{array}{l}\text { General Hospital, } \\
\text { Misau }\end{array}$ & 15 \\
\hline \multirow[t]{4}{*}{ Borno } & $\begin{array}{l}\text { General Hospital, } \\
\text { Mongunu }\end{array}$ & 14 \\
\hline & Borno State & 21 \\
\hline & Specialist Hospital & \\
\hline & General & 18 \\
\hline \multirow[t]{5}{*}{ Gombe } & General Hospital, & 15 \\
\hline & General & 17 \\
\hline & Hospital, Biliri & \\
\hline & Specialist & 18 \\
\hline & Hospital, Gombe & \\
\hline \multirow[t]{5}{*}{ Taraba } & $\begin{array}{l}\text { General Hospital, } \\
\text { Wukari }\end{array}$ & 20 \\
\hline & General & 15 \\
\hline & Hospital, Zing & \\
\hline & Government & 14 \\
\hline & House Clinic & \\
\hline \multirow[t]{5}{*}{ Yobe } & $\begin{array}{l}\text { General Hospital, } \\
\text { Gashua }\end{array}$ & 16 \\
\hline & General Sani & 19 \\
\hline & Abacha Specialist & \\
\hline & Hospital, Damaturu & \\
\hline & $\begin{array}{l}\text { General Hospital, } \\
\text { Potiskum }\end{array}$ & 18 \\
\hline Total & & 299 \\
\hline
\end{tabular}




\begin{tabular}{|c|c|c|c|c|c|c|}
\hline Variable & $\begin{array}{c}\text { Nurses } \\
n=149(\%)\end{array}$ & $\begin{array}{l}\text { Laboratory } \\
\text { scientists } \\
n=26(\%)\end{array}$ & $\begin{array}{l}\text { Pharmacists } \\
n=10(\%)\end{array}$ & $\begin{array}{c}\text { Doctors } \\
n=33(\%)\end{array}$ & $\begin{array}{c}\text { Other } \\
\text { support staff } \\
n=81(\%)\end{array}$ & $\begin{array}{c}\text { Total } \\
n=299(\%)\end{array}$ \\
\hline \multicolumn{7}{|l|}{ Sex } \\
\hline Female & 75 (50.33) & $6(23.1)$ & $8(80.0)$ & $2(6.1)$ & 17 (21.0) & $108(36.1)$ \\
\hline Male & 74 (49.7) & 20 (76.9) & $2(20.0)$ & 31 (93.9) & 64 (79.0) & $191(63.9)$ \\
\hline \multicolumn{7}{|c|}{ Age (years) } \\
\hline $20-30$ & $3(2.0)$ & 0 & $4(40.0)$ & $2(6.1)$ & 10 & $19(6.4)$ \\
\hline $31-40$ & $68(45.7)$ & $24(92.3)$ & $6(60.0)$ & $17(51.5)$ & 43 & $158(52.8)$ \\
\hline $41-50$ & 78 (52.3) & $2(7.7)$ & 0 & $14(42.4)$ & 28 & $122(40.8)$ \\
\hline $51-60$ & 0 & 0 & 0 & 0 & 0 & 0 \\
\hline $61-70$ & 0 & 0 & 0 & 0 & 0 & 0 \\
\hline \multicolumn{7}{|c|}{$\begin{array}{l}\text { Number of years } \\
\text { on present job }\end{array}$} \\
\hline $0-5$ & 18 (12.1) & $2(7.7)$ & $6(60.0)$ & $7(21.2)$ & $4(4.9)$ & 37 (12.4) \\
\hline $5-10$ & $22(14.8)$ & $14(53.8)$ & 0 & $10(30.3)$ & $34(42.0)$ & $80(26.8)$ \\
\hline $11-20$ & $33(22.1)$ & $8(30.8)$ & 0 & $10(30.3)$ & $23(28.4)$ & 74 (27.7) \\
\hline $21-30$ & $40(26.8)$ & $2(7.7)$ & $4(40.0)$ & $6(18.2)$ & $20(24.7)$ & $72(24.1)$ \\
\hline $31-40$ & $36(24.2)$ & 0 & 0 & 0 & 0 & $36(12.0)$ \\
\hline
\end{tabular}

\section{Workload and remuneration}

The average number of hours worked per week by nurses/midwives was 45.40 (maximum, 75; minimum, 29; inter-quartile range, 40 hours); laboratory scientists, 47.8 (maximum, 84; minimum, 30; inter-quartile range, 40 hours); pharmacist, 54.9 (maximum, 70; minimum, 40; inter-quartile range, 62 hours); doctors, 52.70 (maximum, 89; minimum, 25 ; inter-quartile range, 49 hours); other support staff, 50.1 (maximum, 85; minimum, 30; interquartile range, 45 hours) [Table 3]. One hundred ninety-five $(65.2 \%)$ workers were happy with their workload, whereas $72(24.0 \%)$ felt overworked and $16(5.4 \%)$ felt their expertise was under-utilized. Majority $(38,12.7 \%)$ of health personnel who felt overworked were nurses [Table 4].

The average income of nurses/midwives was US \$312.76 (maximum, US \$466.66; minimum, US \$75.00; inter-quartile range, US \$291.66); laboratory scientists, US $\$ 321.76$ (maximum, US $\$ 478.00$; minimum, US $\$ 66.66$; inter-quartile range, US \$333.33); pharmacists, US $\$ 354.83$ (maximum, US $\$ 354.83$; minimum, US $\$ 354.83$; inter-quartile range, US \$354.83); doctors, US $\$ 639.64$ (maximum, US $\$ 900.00$; minimum, US $\$ 441.66$; inter-quartile range, US \$591.66); other support staff, US $\$ 155.66$ (maximum, US $\$ 483.33$; minimum, US $\$ 56.66$; inter-quartile range, US \$93.87). Two hundred thirtytwo $(77.6 \%)$ of the respondents were paid regularly as and when due. One hundred fifty-four (51.5\%) respondents were not satisfied with their present salaries; of these, nurses/midwives constituted the greatest proportion $(77,25.8 \%)$ [Table 4].

\section{Supervision and interpersonal relationships}

One hundred sixty-six (55.5\%) workers required supervision to be able to work well. Amongst the different cadres of health care workers, 97 (65.1\%) nurses/midwives, 16 (61.5\%) laboratory scientists and 37 (47.7\%) other support staff needed supervision to work well. Interpersonal relationships were viewed as "very open" and "open" by 147 (49.2\%) and 97 (32.4\%) workers, respectively. Two hundred seventy-eight (92.9\%) workers felt co-workers were supportive.

\section{Workplace characteristics}

Two hundred $(66.9 \%)$ respondents found their workplace inspiring, 82 (27.4) found the workplace uninspiring and 17 (5.7\%) did not respond to the question. One hundred three $(69.1 \%)$ nurses/ midwives, 16 (61.5\%) laboratory workers, $8(80.0 \%)$ pharmacists, $20(60.6 \%)$ doctors and $53(65.4 \%)$ of other support staff found their workplace inspiring. Two hundred forty $(80.3 \%)$ of the respondents felt an attainment of progress towards achieving personal professional goals [Table 5].

\section{Managerial characteristics}

One hundred four $(34.8 \%)$ of the health workers felt management of their hospitals was very open, $119(39.8 \%)$ felt the management was open, $14(4.7 \%)$ felt the management was guarded. Two hundred forty-nine (83.3\%) workers felt the management of their hospitals was supportive of staff welfare. Two hundred nineteen $(2.2 \%)$ workers felt the management of the hospital was supportive of staff training and development, and 199 (66.6\%) felt they could express themselves without fear of retribution. Managerial characteristics that motivated health workers were good interpersonal relationships (59,19.7\%), good welfare package for staff $(49,32.9 \%)$, career development $(27,9.0 \%)$, freedom of expression (25, 8.4\%); while 88 (29.4\%) workers did not respond to this question 


\begin{tabular}{|c|c|c|c|c|c|}
\hline Variable & $\begin{array}{c}\text { Nurses/midwives } \\
n=149\end{array}$ & $\begin{array}{c}\text { Laboratory } \\
\text { scientists } \\
n=26\end{array}$ & $\begin{array}{c}\text { Pharmacists } \\
n=10\end{array}$ & $\begin{array}{l}\text { Doctors } \\
n=33\end{array}$ & $\begin{array}{l}\text { Other support } \\
\text { staff } n=81\end{array}$ \\
\hline \multicolumn{6}{|l|}{ Hours/week } \\
\hline Mean & 46.40 & 50.72 & 62 & 52.70 & 50.1 \\
\hline Maximum & 80 & 84 & 80 & 89 & 84 \\
\hline Minimum & 29 & 30 & 40 & 25 & 30 \\
\hline \multicolumn{6}{|l|}{$\begin{array}{l}\text { Income/ } \\
\text { month US \$ }\end{array}$} \\
\hline Mean & 312.76 & 321.76 & 354.83 & 639.64 & 155.66 \\
\hline Maximum & 466.66 & 478.00 & 354.83 & 900.00 & 483.33 \\
\hline Minimum & 75.00 & 66.00 & 354.83 & 441.66 & 155.66 \\
\hline
\end{tabular}

\begin{tabular}{|c|c|c|c|c|c|c|}
\hline Variable & $\begin{array}{c}\text { Nurses/ } \\
\text { midwives } \\
n=149(\%)\end{array}$ & $\begin{array}{c}\text { Laboratory } \\
\text { scientists } \\
n=26(\%)\end{array}$ & $\begin{array}{c}\text { Pharmacists } \\
n=10(\%)\end{array}$ & $\begin{array}{c}\text { Doctors } \\
n=33(\%)\end{array}$ & $\begin{array}{c}\text { Other } \\
\text { support staff } \\
n=81(\%)\end{array}$ & Total (\%) \\
\hline \multicolumn{7}{|l|}{ Perception of workload } \\
\hline Happy and satisfied & 89 (59.7) & $16(61.5)$ & $10(100)$ & $16(48.5)$ & $64(79.0)$ & $195(65.2)$ \\
\hline Overworked & $38(25.5)$ & $4(15.4)$ & 0 & $13(39.4)$ & $17(21.0)$ & $72(24.0)$ \\
\hline Under-utilized & $10(6.7)$ & $6(23.1)$ & 0 & 0 & 0 & $16(5.4)$ \\
\hline No response & $12(8.0)$ & 0 & 0 & $4(12.1)$ & 0 & $16(5.4)$ \\
\hline \multicolumn{7}{|l|}{$\begin{array}{l}\text { Remunerated as } \\
\text { and when due }\end{array}$} \\
\hline Yes & $111(74.5)$ & $24(92.3)$ & $10(100)$ & $28(84.8)$ & $59(72.8)$ & $232(77.6)$ \\
\hline No & $38(25.5)$ & $2(7.7)$ & 0 & $5(15.2)$ & $22(27.2)$ & $67(22.4)$ \\
\hline \multicolumn{7}{|l|}{$\begin{array}{l}\text { Satisfaction with } \\
\text { present remuneration }\end{array}$} \\
\hline Yes & $63(42.3)$ & $10(38.5)$ & $8(80.0)$ & $13(39.4)$ & $35(43.2)$ & $129(43.1)$ \\
\hline No & 77 (51.7) & $14(53.8)$ & $2(20.0)$ & $20(60.6)$ & $41(50.6)$ & $154(51.5)$ \\
\hline Don't know & $9(6.0)$ & $2(7.7)$ & 0 & 0 & $5(6.2)$ & $16(5.4)$ \\
\hline
\end{tabular}

\begin{tabular}{|c|c|c|c|c|c|c|}
\hline Variable & $\begin{array}{c}\text { Nurses } n=149 \\
(\%)\end{array}$ & $\begin{array}{l}\text { Laboratory } \\
\text { scientists } \\
n=26(\%)\end{array}$ & $\begin{array}{l}\text { Pharmacists } \\
n=10(\%)\end{array}$ & $\begin{array}{c}\text { Doctors } \\
n=33(\%)\end{array}$ & $\begin{array}{c}\text { Other } \\
\text { support staff } \\
n=81(\%)\end{array}$ & $\begin{array}{c}\text { Total } \\
n=299(\%)\end{array}$ \\
\hline \multicolumn{7}{|c|}{$\begin{array}{l}\text { Attainment of progress } \\
\text { towards achievement of } \\
\text { personal professional goals }\end{array}$} \\
\hline Yes & $120(80.5)$ & 24 (92.3) & $4(40.0)$ & $23(69.7)$ & $69(85.2)$ & $240(80.3)$ \\
\hline No & $27(18.1)$ & 2 (7.7) & $2(20.0)$ & $8(24.2)$ & $11(13.6)$ & $50(16.7)$ \\
\hline Don't know & $2(1.3)$ & 0 & $4(40.0)$ & $2(6.1)$ & $1(1.2)$ & $9(3.0)$ \\
\hline \multicolumn{7}{|l|}{$\begin{array}{l}\text { Workplace } \\
\text { is inspiring }\end{array}$} \\
\hline Yes & $103(69.1)$ & $16(61.5)$ & $8(80.0)$ & $20(60.6)$ & $53(65.4)$ & $200(66.9)$ \\
\hline No & $40(26.8)$ & $6(23.1)$ & $2(20.0)$ & $11(33.3)$ & $23(28.4)$ & $82(27.4)$ \\
\hline Don't know & $6(4.1)$ & $4(15.4)$ & 0 & $2(6.1)$ & $5(6.2)$ & $17(5.7)$ \\
\hline
\end{tabular}

[Table 6]. One hundred twenty-one (40.5\%) workers said consumables were made available irregularly, while 111 (37.1\%) said consumables were made available regularly but in limited quantity [Table 6].

\section{General job satisfaction}

Two hundred four $(68.2 \%)$ workers experienced satisfaction with their current jobs, 89 (29.8\%) were not satisfied, while $6(2.0 \%)$ workers did not respond to this question.
General job satisfaction was not related to sex $(P=0.832)$, type of profession $(P=0.097)$, age $(P=0.814)$ and number of years on the current job $(P=0.945)$. However, presence of conflict at work $(P=0.001)$, freedom of expression $(P>0.001)$, managerial support for staff welfare $(P>0.001)$, managerial support for staff career and development $(P>0.001)$, availability of tools and consumables in the workplace $(P>0.001)$, progress towards personal professional goals $(P=0.001)$ were related to general job satisfaction. 


\begin{tabular}{|c|c|c|c|c|c|c|}
\hline \multicolumn{7}{|c|}{ Table 6: Managerial characteristics } \\
\hline Variable & $\begin{array}{c}\text { Nurses } \\
n=149(\%)\end{array}$ & $\begin{array}{l}\text { Laboratory } \\
\text { scientists } \\
n=26(\%)\end{array}$ & $\begin{array}{l}\text { Pharmacists } \\
n=10(\%)\end{array}$ & $\begin{array}{c}\text { Doctors } \\
n=33(\%)\end{array}$ & $\begin{array}{c}\text { Other } \\
\text { support staff } \\
n=81(\%)\end{array}$ & $\begin{array}{c}\text { Total } \\
n=299(\%)\end{array}$ \\
\hline \multicolumn{7}{|l|}{$\begin{array}{l}\text { Managerial } \\
\text { openness to staff }\end{array}$} \\
\hline Very open & $46(30.9)$ & $8(30.8)$ & 0 & $12(36.4)$ & $38(46.9)$ & $104(34.8)$ \\
\hline Open & $67(45.0)$ & $16(61.5)$ & 0 & $15(45.5)$ & $21(25.9)$ & $119(39.8)$ \\
\hline Guarded & $31(20.8)$ & 0 & $10(100)$ & $5(15.2)$ & $16(19.8)$ & $62(20.7)$ \\
\hline Highly guarded & $5(3.4)$ & $2(7.7)$ & 0 & $1(3)$ & $6(7.8)$ & $14(4.7)$ \\
\hline \multicolumn{7}{|l|}{$\begin{array}{l}\text { Managerial support } \\
\text { for staff welfare }\end{array}$} \\
\hline Very supportive & $28(18.8)$ & $4(15.4)$ & 0 & $4(12.1)$ & 38 (46.9) & $74(24.7)$ \\
\hline Supportive & $63(42.3)$ & $14(53.8)$ & $10(100)$ & $20(60.6)$ & $28(34.6)$ & $135(45.2)$ \\
\hline Unsupportive & $50(33.6)$ & $4(15.4)$ & 0 & $5(15.2)$ & $12(14.8)$ & $71(23.7)$ \\
\hline Antagonistic & $8(5.4)$ & $2(7.7)$ & 0 & $2(6.1)$ & $1(1.2)$ & $13(4.4)$ \\
\hline No response & 0 & $2(7.7)$ & 0 & $2(6.1)$ & $2(2.5)$ & $6(2.0)$ \\
\hline \multicolumn{7}{|l|}{$\begin{array}{l}\text { Managerial support } \\
\text { for staff training } \\
\text { and development }\end{array}$} \\
\hline Very supportive & $33(22.1)$ & $4(15.4)$ & 0 & $4(12.1)$ & $32(39.5)$ & $73(24.4)$ \\
\hline Supportive & $78(52.3)$ & $18(69.2)$ & 0 & $18(54.5)$ & $32(39.5)$ & $146(48.8)$ \\
\hline Unsupportive & $20(20.1)$ & $4(15.4)$ & $2(20)$ & 10 (30.3) & $11(13.6)$ & $57(19.1)$ \\
\hline Antagonistic & $4(2.7)$ & 0 & $8(80)$ & 13.0 & $2(2.5)$ & $15(5.0)$ \\
\hline No response & $4(2.7)$ & 0 & 0 & 0 & $4(4.9)$ & $8(2.7)$ \\
\hline \multicolumn{7}{|l|}{$\begin{array}{l}\text { Freedom of } \\
\text { expression in the } \\
\text { organization }\end{array}$} \\
\hline Yes & $92(61.7)$ & $20(76.9)$ & $2(20)$ & $20(60.6)$ & $65(80.2)$ & 199 (66.6) \\
\hline No & $54(36.3)$ & $6(23.1)$ & $8(80)$ & $13(39.4)$ & $16(19.8)$ & $97(32.4)$ \\
\hline Don't know & $3(2.0)$ & 0 & 0 & 0 & 0 & $3(1.0)$ \\
\hline \multicolumn{7}{|l|}{$\begin{array}{l}\text { Organizational } \\
\text { characteristics that } \\
\text { motivate workers }\end{array}$} \\
\hline $\begin{array}{l}\text { Good welfare } \\
\text { package for staff }\end{array}$ & 27 (18.1) & 0 & 0 & $2(6.1)$ & $20(24.7)$ & 49 (32.9) \\
\hline $\begin{array}{l}\text { Salary and } \\
\text { other payments } \\
\text { are regular }\end{array}$ & $15(10.1)$ & 0 & 0 & $1(3.0)$ & $2(2.5)$ & $18(12.1)$ \\
\hline $\begin{array}{l}\text { Good interpersonal } \\
\text { relationships }\end{array}$ & $25(16.8)$ & $10(38.5)$ & 0 & $14(42.5)$ & $10(12.3)$ & $59(39.6)$ \\
\hline $\begin{array}{l}\text { Availability of } \\
\text { materials to } \\
\text { work with }\end{array}$ & $6(4.0)$ & $2(7.7)$ & 0 & 0 & $8(9.9)$ & $16(10.7)$ \\
\hline Fairness & $7(4.7)$ & $4(15.4)$ & $2(20)$ & 0 & $4(4.9)$ & $17(11.4)$ \\
\hline $\begin{array}{l}\text { Help to achieve } \\
\text { personal goals }\end{array}$ & $7(4.7)$ & 0 & 0 & $6(18.2)$ & 14 (17.3) & 27 (14.1) \\
\hline $\begin{array}{l}\text { Freedom of } \\
\text { expression }\end{array}$ & 0 & 0 & 0 & $2(6.1)$ & $23(28.4)$ & $25(16.8)$ \\
\hline No response & $62(41.6)$ & $10(38.5)$ & $8(80)$ & $8(24.2)$ & 0 & 88 (59.1) \\
\hline
\end{tabular}

\section{Discussion}

Findings from this study revealed that $65.2 \%$ of the respondents were happy with their workload, and $77.6 \%$ were paid as and when due; however, about half $(51.5 \%)$ of the respondents felt underpaid for the work they did. It was unexpected to find such a high proportion of health workers feeling satisfied with their salaries in view of the fact that a major cause of health worker migration in Africa is better remuneration. ${ }^{[11]}$ The study also showed that nonmonetary factors such as interpersonal relationships, quality of supervision, availability of tools and equipment to work with, as well as managerial fairness, support for staff welfare and training, appear to play a significant role in affecting health workers' satisfaction with their work. This agrees with findings from studies done in Ghana and Mali. ${ }^{[3,11,12]}$ Other studies of worker motivation in African countries have also shown that nonmonetary factors play a role in affecting worker motivation and job satisfaction. ${ }^{[13]}$ However, the media and the information sector tend to portray monetary benefits as being a major factor in worker motivation and staff retention, at least in Nigeria. Little light is shed on nonmonetary factors. 
The nonmonetary factors that would positively motivate health personnel include improved staff welfare, managerial support for career development, improved quality of supervision and adequate availability of tools and equipment to work with. It appears that the workers' psychological well-being is important for job retention. Organizations can manipulate these factors to retain staff and improve the output of their staff. Absence of these positive factors has been shown to lead to daily unresolved frustrations in workers in the health care sector, which in turn reduce their willingness to exert and maintain efforts towards attaining the stated organizational goal of providing high-quality care. Moreover, their pent-up frustrations are sometimes directed towards the clients in the form of rudeness, anger, unfriendly behavior and resentment. ${ }^{[14]}$ This may, to some extent, explain the reason for the poor quality of health care seen in Nigeria and other developing countries. Though salaries and regularity of payments were viewed as important by workers, nonmonetary factors like quality of supervision, availability of tools and materials to work with, staff welfare and career development also appear to be important in creating satisfaction with job environment.

More research needs to be carried out to fully understand factors that motivate health workers and cause job satisfaction amongst them in Nigeria and other resource-poor regions.

\section{Acknowledgments}

Authors wish to acknowledge the contribution of the following persons: Professor J. Idoko of the Department of Internal Medicine, Faculty of Medicine, University of Jos; and Mr. David Ochi and Mrs. Monica Moru of Halt AIDS, Jos.

\section{References}

1. Bennett S, Lynne MF. Public Sector Health Worker Motivation and Health Sector Reform: A Conceptual Framework. Major Applied Research 5, Technical Paper 1.
Bethesda, MD: Partnerships for Health Reform Project, Abt Associates Inc; January 1999.

2. Marjolein Dieleman, Pham Viet Cuong, Le Vu Anh and Tim Martineau. Identifying factors for job motivation of rural health workers in North Viet Nam. Hum Resour Health 2003; 1:10.

3. Dieleman M, Toonen ], Touré H, Martineau T. The match between motivation and performance management of health sector workers in Mali. Hum Resour Health 2006;4:2.

4. Franco LM, Bennett S, Kanfer R. Health sector reform and public sector health worker motivation a conceptual framework. Soc Sci Med 2002;54:1255-66.

5. World Health Organization: Training manual on management of human resources for health. Section I, part A. Geneva 1993.

6. Martinez ]. Assessing quality, outcome and performance management. Geneva: World Health Organization; 2001.

7. Franco L.M, Bennett S, Kanfer R and Stubblebine P. Determinants and consequences of health worker motivation in hospitals in Jordan and Georgia. Soc Sci Med 2004;58:343-55.

8. Gilson L, Alilio M, Heggenhougen K. Community satisfaction with primary health care services: An evaluation undertaken in the Morogoro region of Tanzania. Soc Sci Med 1994;39:767-80.

9. Stilwell B. Managing brain drain and brain waste of health workers in Nigeria. Bull World Health Organ 2004;82:595-600.

10. David Johnson. Nigeria: A paper produced by DFID's Health Systems Resource Centre for the UK Department for International Development. October 2000.

11. Stilwell B, Diallo K, Zurn P, Vujicic M, Adams O, Dal Poz M. Migration of health-care workers from developing countries: Strategic approaches to its management. Bull World Health Organ 2004;82:595-600.

12. Agyepong IA, Anafi P, Asiamah E, Ansah EK, Ashon DA, Narh-Dometey C. Health worker (internal customer) satisfaction and motivation in the public sector in Ghana. Int ] health Plann Mgt 2004;19:319-36.

13. Al Hussein S, Kumako B, Ananga P, Dzikunu H, Richardson R. Should the nurse be blamed? Int Nursing Rev 1993;40:27-8.

14. Bennett S, Franco LM. PHR Primer for Policymakers. Health Worker Motivation and health sector reform. PHR Information and Communications, Abt. Associates Inc., 4800 Montgomery Lane, Suite 600. Bethesda, MD 20814, USA. Available from: Http://www.PHRproject.com. [cited in 2000].

Source of Support: Nil, Conflict of Interest: None declared.
Page | 249 